\title{
Ippolito Nievo: Portrait of the Writer as an Old Man
}

\author{
Chiara Nannicini
}

University St. Louis Brussels

\begin{abstract}
Ippolito Nievo's long autobiographical novel, Confessions of an Italian (Confessioni di un italiano), also known as 'Confessions of an Octogenarian' (Confessioni di un ottuagenario), in reference to its 80 -year-old narrator, was actually written when the writer was...twenty-nine. The narrator takes on the role of an old man reflecting on his own life - from childhood, through youth until middle and old age - making the reader believe that he is dealing with the memories of a life already lived. Indeed, Nievo must have taken inspiration from his grandfather's life at the turn of the nineteenth century to which he added his own experience. The irony of fate is well-known: The author died at the age of 29 and the unfinished novel was published in 1867, six years after his death. Since then, it has remained an outstanding literary specimen in both Italian and European literature. In this paper, we will dwell in particular on the clever outline of the narrator. The distance between the real and the fake narrator certainly belongs to the purest autobiographical tradition, and yet it offers here a further challenge to the writer, constantly trying to share his lifelong experience with the reader and the character himself. All things considered, Nievo foresaw both his own life and how he would have written it, as if he had already lived it and was about to die.
\end{abstract}

Keywords: Ippolito Nievo, confessions, autobiography, death, old age

\section{RIASSUNTO IN ITALIANO}

Il lungo romanzo di spunto autobiografico che ci ha lasciato Ippolito Nievo, Confessioni di un Italiano, noto anche come Confessioni di un ottuagenario in riferimento al suo narratore ottantenne, fu in realtà scritto quando l'autore aveva... ventinove anni. L'istanza narrativa assume il ruolo di un anziano che riflette 
sulla propria vita - dall'infanzia, passando dall'età adulta per arrivare alla vecchiaia - facendo credere al lettore di raccontare fatti di una vita già vissuta. Per raggiungere il suo scopo, Nievo si è ispirato alla vita del nonno, a cavallo tra i due secoli, a cui ha aggiunto la propria esperienza autobiografica. L'ironia della sorte è tristemente nota: lo scrittore morì a ventinove anni, lasciando che il suo romanzo fosse pubblicato postumo, nel 1867, sei anni dopo la sua morte. Da allora, il suo capolavoro letterario costituisce un caso straordinario, sia per la letteratura italiana che per quella europea. In questo articolo, si tratterà soprattutto di analizzare la figura del narratore, delineata da Nievo con grande maestria. La distanza tra il narratore reale e quello fittizio appartiene sicuramente alla più pura tradizione autobiografica, eppure si constata qui una sfida supplementare per lo scrittore, il quale cerca continuamente di simulare come il personaggio narratore possa far frutto di un'esperienza di vita decennale, condividerla con il lettore e prepararsi a lasciarla. In fin dei conti, Nievo anticipò nel contempo sia il corso della propria vita sia la maniera di scriverla, come se l'avesse già vissuta, e come se fosse in procinto di morire.

Keywords: Ippolito Nievo, Confessioni, Autobiografia, Morte, Vecchiaia

Confessioni di un italiano, Ippolito Nievo's most important novel, was written in 1858, some weeks before the young writer, born in 1831, would join Garibaldi's army for the well-known Expedition of the Thousand to fight for Italian unification. According to the legend, he left his manuscript in the top drawer of his bedside desk, written in eight months and copied in one month in his nice handwriting. This voluminous work, translated into English as Confessions of an Italian, ${ }^{1}$ is considered one of the most important Italian novels of the nineteenth century, together with Manzoni's and Verga's works, published respectively twenty years before and after Nievo's. No wonder that Nievo is one of the most studied writers of this period and that several essays are dedicated to his work, mostly to his collection of short stories entitled Novelliere campagnolo $(1855),{ }^{2}$ his rich and very refined correspondence (about 500 letters) ${ }^{3}$ and, of course, his major novel (though most of these works have not been translated into English yet). Unfortunately, Nievo died at the age of 29 in the shipwreck of Ercole, in the night between the fourth and the fifth of March 1861, while he was leaving Sicily for Naples. The mysterious circumstances of his death and the silence of the authorities caused some historians and critics to suspect that the accident was fake, hiding a sabotage, as Nievo held the position of Vice Revenue Officer of Giuseppe Garibaldi's army. His military naval expedition, comprised of a thousand volunteers, left Genoa Quarto in May 1860 towards Sicily with the intention of 'freeing' the South of Italy from Bourbon domination. The position of Revenue officer was similar to 
that of an accountant, which suggests that Giovanni Acerbi (the Chief Revenue Officer) and Nievo probably knew too much about shady business and financing. But this is another question, having inspired many investigations, historical reconstructions, and uncertain hypotheses. As a matter of fact, his premature death surely contributed to create the myth of Nievo, the romantic hero, the soldier poet, the "warrior like Byron and shipwreck victim like Shelley.'

His novel, first published posthumously in 1867, presents the life of Carlo Altoviti as told by himself at the age of 80 . The protagonist, both the novel's hero and its narrator, is believed to have been born in 1775 in the Republic of Venice and to have lived until 1858, which coincides with the moment of writing. The function of the narrator is quite intricate, since it is split into several figures: the fictional old Carlo, the fictional young Carlo and the omniscient storyteller. But even more complicated is the reflection on Nievo's narrative choices. It is quite clear that Nievo's Confessions belongs to the tradition of the autobiographical novel, since the "identity between the author of the text, the narrator of the story, and the character that is being told about' ${ }^{5}$ is not made explicit. As recent research shows, we cannot speak of a single autobiographical genre, but should instead speak of many different ones. ${ }^{6}$ The only remaining valid criterion for distinction seems to be Philippe Lejeune's well-known concept of the 'autobiographical pact' based on a tacit agreement between the author/narrator and the reader. ${ }^{7}$ According to Martina Wagner-Egelhaaf, autobiography 'is no longer an essentialist category, but a dimension, or better a constitutive element of the literary communication. ${ }^{8}$

In fact, Nievo makes extensive use of this autobiographical pact and includes, from the beginning, some of the usual 'autobiographical signs ${ }^{\prime}$ suggesting to the reader that he/she is faced with an autobiography:

I was born a Venetian on 18 October 1775, the day of Saint Luke of the Gospel, and by God's grace I shall die an Italian, whenever that Providence that so mysteriously governs the world deems it right.

That is the moral of my story. And since it wasn't I but my times that wrote the moral, it occurs to me that a simple account of how my times acted upon my life might be of some use to those destined one day to know the full consequences of what was just beginning here. ${ }^{10}$

This famous incipit adheres to autobiographical conventions, such as providing the date of birth, a geographical location (contained in Venetian), the announcement of a life-long story and especially the reason to write it. Actually, the old Carlo's voice affirms that the story of his life can be useful for his contemporaries, in what he will later call 'this age of transition': ${ }^{11}$ He means the historical process and succession of events leading 
to the Italian political unification in 1861 (1870 for Venice) that is still ongoing at the moment of writing. The telling of a life as a lesson for posterity is the founding element of every historical autobiography, in which authors combine their private and individual stories with official history, hence, presenting themselves and adopting the mission of being a witness of their times. From a historical point of view, Nievo's novel offers a precious documentation of the decline of Venice, the loss of its centuries-old independence in the Napoleonic era in 1797, after which it became an Austrian province. But it also gives further information about the Risorgimento period in the first half of the nineteenth century, the time of political and social revolution, which created Italy as a political entity. The critics agree: no other Italian novel gives such a frank account of the Risorgimento, ${ }^{12}$ exploring people's thoughts at the time in both the liberal and the conservative parties. Nievo did not only study the last years of Venetian history, ${ }^{13}$ but he also recalled and developed the experience of his maternal grandfather, Carlo Marin, who lived during this period similarly to his homonymous fictional Carlo - and told his grandson much about it in the 1840s ${ }^{14}$ Critics are inclined to think that Carlo Marin is the main model for the creation of the fictional character, although some of them recently rejected this theory. As a historical novel, Nievo's book is quite isolated in Italian literature. Rather than referring to past events, as Manzoni does ${ }^{15}$ Nievo based his novel on contemporary history like other European writers, such as Walter Scott (Waverley), Stendhal (The Charterhouse of Parma), or even Tolstoy, whose War and Peace has so often been compared to Nievo's Confessions ${ }^{16}$ But if we take up the concept of the autobiographical novel, we can observe that Nievo's narrative choices exceed the conventions, because an important part of the story concerns the writer's actual life: The critic Sergio Romagnoli has shown that the last part of the novel is true to the author's biography from 1850 to $1855 .^{17}$ In this section, the writer mixes some ingredients of an 'autobiographical text' with elements of the autobiographical novel proposed in the first part of the book. Due to this complex and innovative structure, the novel escapes any attempt of categorization or labeling.

While it is not my aim to offer a detailed description of Nievo's literary choices, it will be necessary to pose the question of how the writer deals with the issue of the future death of his character, and to what extent autobiographical fiction has influenced this vision and consciousness.

\section{THE VOICE OF AN OLD MAN}

Paradoxically, there seems to be nothing better than an old man's voice to address the theme of the future, but only after demonstrating his 
wisdom and building on his long experience. Of course, old age stands for experience, wisdom, and retrospective judgement - at least in the common opinion: The philosopher Norberto Bobbio, in his essay Old Age, disagrees with some of the stereotypes attributed to the elderly. ${ }^{18}$ In these pages, written at the age of 80 , Bobbio states, for instance, that ' $[t]$ here is no virtue in being eighty years old, not then and still less today. It is simply good fortune. ${ }^{19}$ Apart from Bobbio's unusual point of view, the commonly accepted principle is that older people are endowed with particular wisdom and 'long experience. ${ }^{20}$ An experienced narrator of advanced age who remembers the past from his reliable and venerable point of view may serve as a model, a sort of authority, for the reader. ${ }^{21}$ Nevertheless, for a writer in his twenties, it must have been an effort of imagination to shape the figure of a fictional octogenarian and to let him think and speak in a credible way. Critics often mentioned this 'structural invention' as a 'ruse of the narrative reason' ${ }^{22}$ and illustrate it by many examples, especially concentrated in the book's two strategic points of the incipit and the explicit. These are indeed the two points in which the narrator explicitly presents his presumed age, insisting particularly on the time gap, and justifying the differences in judgment and mind between the young hero and the old narrator. Apart from these famous passages, we can find some returns to the consciousness of the elderly and to the present of the writing in every chapter of the novel. Adverbs such as 'today,' 'nowadays,' 'even now,' and 'meanwhile'23 are almost as frequent as the mentions of 'the old years' and of 'times past.'24 Here are some examples of typical returns to the perspective of an old man:

In his devotion to his own history, man never lets go of passing time; he shapes manhood from his youth, and preserves both youth and manhood in the weary, thoughtful repose of old age.

Women, our superiors! Yes, my brothers: accept this strange judgment from the mouth of [an old] one who has known many of them. ${ }^{25}$

I suggest that the real talent of the writer consists in constantly shifting back to the point of view of the elderly, finding more and more variations to the standard procedure, and adding a pinch of irony in sentences like this: 'I am old but not enamored of age, and as for antiquity, I worship the beard itself, not whether black or grey. ${ }^{, 26}$ The narrator's irony allows him to take some distance from the character, to develop a critical sense towards the narrative situation, and to sublimate the facts with wisdom accumulated over the years. Yet, when the narrator's irony is turned against himself, in a sort of self-irony, Nievo makes good-natured fun of the narrative conventions, the credibility of his character and perhaps 
even a little of the custom, typical of older people, to distribute words of wisdom.

\begin{abstract}
Let us not hurry matters, my friends! After I've walked you round and round in the cheerful, various, densely populated labyrinth of my younger years, you will end up sitting in an armchair where an old man who can barely move his legs nonetheless - with some courage and much thought - invests his hopes in a future that goes far beyond the tomb. ${ }^{27}$
\end{abstract}

With his spicy humour, the writer is able to avoid a trite and stiff attitude, proposing original and constantly changing ideas to renew the words and thoughts of his old narrator. This sense of humour, well analyzed by critics, ${ }^{28}$ seems to be a real heritage of novels written at the Age of Enlightenment, by Voltaire, Diderot, and above all by Laurence Sterne in his Tristram Shandy. The comparison has been suggested and deeply analyzed, especially by Mazzacurati in his critical work. ${ }^{29}$ Sterne is a real master of the fictional and transgressive autobiography, in which the narrator is completely reinvented. We need to remind ourselves that Sterne's Sentimental Journey had been translated into Italian by Ugo Foscolo himself, and Nievo knew it quite well, while Tristram Shandy circulated throughout the nineteenth century, in Italy, in Wailly's French translation, and was translated into Italian only in $1922 ;{ }^{30}$ yet it has been well proven that Nievo was also familiar with the great Sternian novel. ${ }^{31}$

Far from denying the originality of Nievo's work, ${ }^{32}$ this analogy allows us to shed new light on some of his narrative processes, such as the dialogue with the reader, the liking for digressions, the multiple facets of the narrator, and moments of writing. Sterne went farther, indeed, creating a digressive, self-critical novel that relegated the plot to secondary importance, which differs profoundly from Nievo's choices. Yet, the narrator Tristram Shandy who recounts his life, ironically and sovereignly, sometimes seems to echo in Carlo Altoviti's voice, in what the critics define as 'sentimental humour. ${ }^{33}$ The ironic detachment of both narrators plays down the role of the traditional oracle of wisdom, introducing unusual elements into the history of life, promptly changing style or suddenly going from deep reflection to a witticism in order to break the expectations of the reader.

The author's irony spreads everywhere and finds several targets in some unforgettable characters moving in the Fratta Castle, where Carlo spent his childhood. This 'conventional puppet theatre of Fratta's high society' (as Falcetto aptly describes it), ${ }^{34}$ which corresponds to the first five chapters of the novel, is a skillful device, among the best of the book, for the clever and refined description of the outdated and anachronistic 
aristocracy of the Venetian Republic with all its human variety. The ironic tone slipped into this section, which emphasizes the gap between young Carlo and old Carlo, is particularly successful. Let us consider two examples. Carlino was orphaned and subsequently adopted by his aunt, the countess of Fratta, but she only did so because she had no choice. The child is terrified by 'her dictatorship,' as the narrator retrospectively calls it, although his fear - far from other nineteenth century's novels presenting a similar situation (Jane Eyre, Oliver Twist) - makes us laugh rather than cry.

I saw my aunt's white cap appear in the entrance hall. I can call her aunt now, poor thing, that she is dead a good half-century, but back then, as soon as I was capable of speaking, they taught me, at her command, to call her Madam Countess. ${ }^{35}$

The dissatisfied countess, who nostalgically remembers the amorous successes of her youth and is now enclosed in the Fratta castle like a museum piece, particularly inspires the satirical vein of the author, whose targets belong always to the old age, never to the juvenile one. For example, her discontent is compared to the peace of mind of his brother-in-law, monsignor Orlando, in these terms:

Heavens! There was a reason of course! Monsignor Orlando had confined all happiness to satisfy the pleasure of the stomach, a passion that can burn - and rather brightly too - in old age. While she on the other hand... oh please! I don't wish to go on, now that her skeleton has been polished by fifty years underground. ${ }^{36}$

This thought appears to reflect the point of view of the elderly narrator whose critical distance is often well defined by a clear reference to the period of time that has passed ( 50 years from the countess' death). Nevertheless, we often observe an excessive insistence on chronological clarification, as if the author wants to constantly remind the reader of the narrator's old age, assuring them of its plausibility. Yet the venerable age of the narrator has been well exposed on the first pages, as is usual, and repeated in the digressive moments, the long gnomic parentheses gushing out from the reflections of the old man (reflections on the unequal flow of time, on ancient virtues, on 'philosophy of the history,' as Maffei wrote).$^{37}$ It would not be necessary to reiterate the exact age of the narrator again and again, even when he takes up the narrative thread of his story. The obsessive repetition of the age brings to light a discrepancy between old age and youth, which I would like to analyze briefly. 


\section{THE PREDILECTION FOR YOUTH}

There is a discrepancy in the novel between the apparent superiority of old age, required by the stylistic-literary format of the novel, and the substantial predilection for the youth, visible from several perspectives. Despite the narrative perspective that filters the recalled events through a consciousness of the elderly, and despite the repeated hints mentioned above that are supposed to "connote the superior wisdom of the old man, ${ }^{, 38}$ the eulogy of youth sovereignly reigns over the novel.

Thus, an important aspect to consider is the novel's structural balance. The book consists of twenty-three chapters, with the story of Carlo's life from childhood to the moment in which the pen falls from the narrator's hands. Yet, the distribution of the chapters does not follow the chronological length of life and its phases: The first phase, childhood, takes five chapters, one of which tells the story of one single day (the discovery of Carlino's external world when he escapes from the castle and finds the sea). Carlo's adolescence is described at some length, so generally, his youth is a considerable focus in the novel. But then the rhythm speeds up irreversibly. In Chapter 19, which is mathematically over three-quarters of the book, we find Carlo at 34 years of age and his beloved Pisana at 28. An additional chronological leap is found later, when the story of the wedding and the founding of the family - an important step in life, after all - is quickly told. Indeed, the frequent use of adverbs, such as 'quickly' and 'in short,' grows accordingly in this chapter. ${ }^{39}$ Still later in Chapter 19, the children of Carlo and Aquilina, newly born, suddenly are 'ten and twelve' years old..$^{40}$ The narrator often chooses summarizing sentences, such as 'The months went by. ${ }^{41}$ The narrative rhythm becomes so fast that the narrator feels he must justify himself towards the reader:

So the years passed as quickly as months do in youth, although you mustn't think they passed as quickly as it seems in the telling. The longer it takes to recount something, the quicker it often moves in reality. ${ }^{42}$

The events bringing Carlo from Naples to Ponza and to Gaeta, which mean three prisons and a death sentence, are synthetized on three pages in Chapter 20. The following phases of his life are told at a frenetic pace corresponding to the maturity of the character, to the active life, and then the pressing of old age, and the long phase of old age before writing: 18 chapters follow the first 34 years of life, whereas the last five chapters contain the remaining 46. Such dilation of the narrative time for the first part of life and the drastic condensation of the second part can be easily explained by the young age of the writer who draws from the reservoir of 
his own memories for the childhood years. The childhood, so important in this book, is supposed to constitute a real phase of the hero's life ${ }^{43}$ and not just its premise, so that its length is almost excessive compared to the space devoted to the remaining life.

Besides, Nievo spent the summer holidays from 1840 to 1844 in his mother's family castle near Udine, quite similar to Fratta Castle ${ }^{44}$ But this explanation sounds a little bit too simple and reductive in a partially fictional novel: Nievo could have chosen to situate the most important actions of his hero in the years 1830-1850, during a period of his own life. But instead, his choice falls on the end of the previous century, the Napoleonic period, half a century before the author was born, whereas the years Nievo knew best from experience are quickly summarized. I suggest that the dilatation of childhood and youth is motivated by a profound reason underlying the novel, namely that Nievo's Confessions are a novel of youthful strength and energy, impulsiveness, and action. Under the pretense of honoring the peaceful wisdom of the old man telling the story, Nievo praises the opposite qualities found in the young character. And old age comes out somewhat battered by comparison.

This argument contrasts with the general critical line of Nievo studies, where the attitude of alleged old age is taken for granted and commented on as an element of primary importance.$^{45}$ There is an important exception, however: Sergio Romagnoli, one of the most respectable critics, affirms in his essay on Nievo that 'the poetry of the novel is fully young. ${ }^{, 46}$ In his opinion, 'the reenactment of the Fratta world ... is clearly the fruit of a youthful spirit, where there is no praise of past time, dominated by the superior smile of a generation of grandchildren who bends over their grandparents' infancy.' In this approach, 'the octogenarian is an expedient' simply to get up to the contemporary age. ${ }^{47}$ I fully agree with Romagnoli's remarks.

Several indicators underpin my interpretation of the author's preference for youth. First of all, older people are often targeted by the narrator's harsh criticism and bitter irony. The elderly people, rather than being venerable and showing wisdom, become a group in the common theatre, barely tolerated by the youngest: The count of Fratta, far from being the patriarch, shows no initiative of his own and lives glued to the chancellor, his shadow, without whom he feels lost. Monsignor Orlando, the family prelate 'despite his Christian name,' only thinks of eating and is described as not 'the sharpest of blades.' Captain Sandracca, charged with the castle's defense, is 'certainly the tallest man in the jurisdiction but the goodness of grace and beauty had not presided at his birth.' Not satisfied, 'he spent a good hour each day before the mirror making himself much uglier than nature had.' He claims to have been wounded in 
a battle, which took place before his birth and does not demonstrate any courage even at the fateful moment of the castle's siege. Gentleman Mauro Navagero is 'a dull, white, puffy-looking old man; he wore the finery of the patrician, but his stubborn, heavy cough belied his elegant clothes. ${ }^{48}$ Even the old countess (the aunt's mother-in-law, Lady Badoer), formerly praised by the narrator, is reduced to an old and slightly senile lady confined to her rooms. Only Martino, the servant who, to some extent, adopts Carlino, can be considered an exception to the rule, but his deafness excludes him from oral communication and only after his death, thanks to his writings, will he be rediscovered by the young protagonist as a model of virtue.

But overall, the novel predominantly confirms the maxim 'Youth is life's heaven and the old adore cheerfulness, the eternal youth of the heart,' for the young characters like Lucilio, Clara, la Pisana, and Carlo himself are certainly the narrative engine and the radiation centre of energy. Even later in the novel, the most important characters are young: Giulio, Leopardo, Spiro, Aglaura, Bruto, and Aquilina. The older characters who remain excluded from the youth group at the centre of the plot, such as the Jesuit father Pendola, the lawyer Ormenta, the noble Navagero, and the countess of Fratta herself, are resolutely negative: a manipulator and intriguing clergyman, a devious adviser and spy of Venice, a decayed aristocrat who selfishly marries a little girl, and a vicious old woman addicted to a game that squanders the family heritage while being supported by her children. The latter, which should be, in a sense, Carlo's adoptive mother, reaches the peak of negativity. Her old age is immoral, her death a liberation. There is not a trace of wisdom and venerability in her.

The famous passage known as the 'farewell to youth', situated in Chapter 12, seemingly plays an essential role in the evolution of the character and in the development of the story. That is why it often inaugurates the mature part of Carlo's life in the frequent editions in two volumes. But in fact, the narrator's speech here is a pure exercise in eloquence, for the protagonist does not seem to have changed at all in the following chapters:

\footnotetext{
Farewell fresh and carefree youth, eternal joy of all the ancient gods of Olympus, heavenly but fleeting gift to us mortals! Farewell dewy dawns glistening with smiles and vows, clouded only by too brightly coloured illusions! [...] And so they came to an end, those delicious years I lived in the old world: the world of powdered wigs and buli and feudal jurisdiction. ${ }^{49}$
}

This farewell to youth should be called a 'farewell to the world of childhood,' because it comes at the moment when the hero enters active life 
and is about twenty years old. This discourse takes on a new meaning in this context. Without containing the sense of nostalgia felt by an elderly person that would be necessary for the declamation of a 'farewell to youth,' what we actually read could be called 'in praise of youth.'

Now that the young writer's point of view on advanced age and youth has been presented, it will be even more interesting to observe his relationship to 'imminent' death.

\section{FUTURE IMAGINARIES OF DEATH}

Carlo Altoviti's attitude towards approaching death draws on prevalent stereotypes of the judicious and wise narrator: the patient awaiting and awareness of the end, existential fatigue with renunciation of pride, et cetera. I may add that the awareness of imminent death is inextricably linked to the figure of the narrator and to the act of writing one's own memories. That is why the topic, present from the beginning, becomes a sort of leitmotif:

As I near the grave, alone in the world, left behind by friends and enemies alike, with no fears and no hopes that are not eternal, freed by age from those passions that so often deflected my judgement from the true path, and freed, too, from the fleeting siren call of my not very bold ambition, I see that I've harvested a single fruit in my life: peace of mind. ${ }^{50}$

Towards the end of the story, at the moment of conclusion, the theme naturally returns in the words of the narrator, addressing the readers as brothers, since all human beings are equal to the thought of death:

What else could I ask? Nothing, my brothers! I lay my head happily on the pillow of the tomb and watch the great, ideal horizons widen as the earthly ones of my faltering eyes fade. ${ }^{51}$

The only important exception to the Italian tradition is the fact that Carlo does not believe in life beyond death, in the Christian sense. Nievo's attitude towards religion, well outlined by the critic Grazia Melli, ${ }^{52}$ emerges explicitly in several passages of the novel:

Old in years, I rest my head on the pillow of the grave and offer these words of faith to those who no longer believe, but still wish to use their minds in this age of transition. Faith cannot be imposed, not even on oneself. To those who object that my virtuous but pointless effort will have no recompense in time eternal, I say: I am master before other men of my temporal and eternal being. ${ }^{53}$ 
The narrator often repeats that he is not 'a believer,' yet his words are tinged with mysticism and a sense of eternity. Indeed, at the end of his memories, he affirms that 'the peace of old age is a placid gulf that opens, little by little, towards the great, infinite and infinitely peaceful ocean of eternity, ${ }^{54}$ and further on, his thoughts go to his 'brother souls in blood' and to his beloved Pisana, thinking of seeing them again soon, to 'join the airy squadron. ${ }^{55}$ Possibly his thought about death is influenced by that of Ugo Foscolo, the romantic poet, author of the poem 'Of the Sepulchres,' which, moreover, is explicitly mentioned in some philosophical wonderings of the narrator and provides information on Nievo's conception of time:

Those emblems of the past are to the memory of an individual chat a nation's monuments of stone and of art are to posterity. They recall, they celebrate, they fire us up; they are Foscolo's Sepulchres that take us back in thought to speak with the dear departed, and every day for us is a dear departed, an urn of ashes and flowers. Such people as have great monuments to inspire them never disappear completely; and when moribund, come back to life larger and more vigorous than ever. ${ }^{56}$

This conception of time as a personal notion anticipates Bergson's principle of 'pure duration or freedom. ${ }^{57}$ But it also recalls some typically romantic values, such as those of the Italian poet Ugo Foscolo. Death does not divide the soul of the deceased from that of their loved ones, since a 'celestial communion with the cherished dead ${ }^{58}$ shall endure. The grave, the sepulchre, shall be the symbol of this continuity through the communication - not a perceived but a sensual communication - between two entities.

There are some earlier moments in his life in which Carlo is confronted with death: the death of Giulio, his rival in love, his friend with an intense soul but a fragile and sick health, and the suicide of Leopardo, another good friend in prison, when the hero himself waits to be executed after the court's death sentence. Another time, after Carlo has discovered and read the notebooks of Martino, his 'memories and lessons, ${ }^{59}$ he has a dream during the night. And lastly, there is the death of Pisana in London. It would be too long a list to take all those examples into detailed consideration here. The moments when Carlo witnesses Leopardo and Pisana dying are mostly mournful and intense, but easy to link to the literary traditions: The first one is full of references to a sovereign death, of delivering him from physical and sentimental pain, and the second gives vent to Carlo's greatest grief, losing the woman he loves and discovering that she had always loved him too.

The previous dream, or nightmare, presents a vision of death with more complex aspects: the influence of preromantic and sepulchral literature, 
of course, with its characteristic fear of being buried alive (and yet, it is important to remember that Nievo did not know Edgar Allan Poe), but also the identification with the dead friend:

Little by little the air of death up there began to invade my brain: the tears froze on my lashes, my eyes took on a troubled glaze I was hard put to dispel. The fire of life seemed to be going out of me and I was oppressed by the chill, the phantoms, the terrors of life's last agony. For an instant, approaching death, I believed I was Martino and I was astonished to think I had risen from the grave and expected that any moment the gravediggers would come to take me back. This strange and fearful thought widened like the mouth of an abyss; it was no longer a thought but a vision, pure dread. ${ }^{60}$

If the discovery of Martino's deep thought and humble attitude towards life constitutes a real illumination for Carlo and a real change in his behavior, as he shall demonstrate later, we can be sure that the image of death and the 'pure dread' which goes with it has contributed to this considerable evolution of his spirit and the loss of his intellectual pride:

I shrank so much in my own esteem that I recognized myself no more; the memory of that old servant, dead, buried and already devoured by worms, forced me to bow my head and acknowledge that with all my Latin learning, when it came to the true knowledge of life I knew less than the peasants. ${ }^{61}$

To conclude, I would like to quote Giulio Del Ponte's death and his delirium of agony, which seems to be an essential moment of the story. Giulio is 28 years old, he is an intellectual and a writer like Nievo himself. Indeed, some critics saw in this figure an alter ego of the writer. Giulio's words at the end of life are quite cynical and desperate, hopeless and without peace. He regrets not having written a work that remains to posterity and asks for an extension: 'Give me another year, another month, a day of that life of mine once so full, so sure, so vital.' ${ }^{62}$ Then, his delirium shows much more rationality than one would expect:

To die at twenty-eight, greedy for life, avid for the future, mad with pride, replete only with pain and humiliation! To abandon life without a dream, without belief, without an embrace; with only the fear and rage that one has to abandon it! Why were we brought forth? Why did they raise us and get us used to living, as if we were eternal? Why did the nursemaid, teaching us our first word, not say 'death'? ${ }^{63}$

Giulio's delirium is impregnated with literary echoes, especially from the poetic philosophy of Giacomo Leopardi, another important model of Nievo's generation. Leopardi sees in the substantial unhappiness of the 
human being a motive of solidarity and equality, but no hope of eternal life comes to console the cynical suffering and awareness of our ephemeral and mortal life. In the last moments of his life, Giulio speaks like Leopardi, not unlike before, when the words of the narrator seem to re-evoke Foscolo's concepts. In other words, these passages about death become stylistic and literary exercises in which Nievo shows off his culture and his skill. It therefore does not make much sense to find in the words that follow a kind of prophetic vision of one's own death, as it would be easy (and romantic) to hypothesize:

Where are the comforts of wisdom, the illusions of glory, the consolations of love? All has been tossed overboard to escape shipwreck, and when the voracious swell opens its jaws only the helmsman is left, clinging naked and helpless to the highest mast. Struggle and tears are in vain, as are prayers and curses. Destiny is inescapable and the wild noise of waves drowns out the nearby shouts of the furious, the moans of the terrified. Below is nothingness; all around, darkness; above, mystery ${ }^{64}$

In conclusion, the premature death of its author looms over Nievo's Confessions again and again. Perhaps the old voice of the storyteller would not produce so many critical reactions (including mine) if the writer had really died at the age of 80 . And yet, we can wonder about the narrative choice of a young writer, who opted for the autobiography of an old patriot, rather than for the fictional adventures of a young hero. The fact is that the novel contains both, the autobiography and the novel of adventures, the old storyteller and the young hero. But it is precisely this hybrid choice, the contrast between these two poles, that produces an exceptional result, a complex novel suspended between literature and history.

In order to fully understand the scope of the novel, it is important to grasp the importance of the narrative fiction hidden in the old wise figure of the storyteller, which is certainly even more original and refined considering the effort of imagination and identification of such a younger writer. However, I believe that the study of the old narrator should not overshadow the pole of impulsive and irrepressible youth, to which the author devotes the lion's share of the narrative, as I have tried to demonstrate here. Even the reflections on death, linked primarily to the figure of old Carlo, are not disconnected from the leitmotif of youth if we look carefully: not only because almost all the dying people in the novel are still young (no old character is represented in the act of dying, if I'm not mistaken), but because their imaginary notion of death is built with literary echoes, revealing a well-defined stylistic choice: the death of the romantic hero is necessarily young and accompanied by contemporary philosophical reflections. Unfortunately, the real death of Nievo, a young 
hero in full action, seems to reaffirm the conception of death elaborated in the pages of his novel.

\section{WORKS CITED}

Bergson, Henri. Time and Free Will. An Essay on the Immediate Data of Consciousness. Toronto: Great Library Collection, 2015.

Bigazzi, Roberto. 'Da Waverley a Carlino.' In: Mariarosa Santiloni (ed.), Ippolito Nievo: l'avventura del romanzo. Atti della Giornata di Studio all'Università degli Studi di Roma 'Tor Vergata', 11 aprile 2013. Firenze: Franco Cesati, 2013, 17-24.

Bobbio, Norberto. Old Age and Other Essays, Trans. A. Cameron. Cambridge: Polity Press, 2001.

Chaarani Lesourd, Elsa. Ippolito Nievo. Uno scrittore politico. Venezia: Marsilio, 2011.

Di Benedetto, Arnaldo. Ippolito Nievo e altro Ottocento. Napoli: Liguori, 1996.

Dionisotti, Carlo. 'Appunti sul Nievo.' In: Appunti sui moderni. Foscolo, Leopardi, Manzoni e gli altri. Bologna: Il Mulino, 1988.

Falcetto, Bruno. L'esemplarità perfetta. Le 'Confessioni’ di Ippolito Nievo. Venezia: Marsilio, 1998.

Foscolo, Ugo. I Sepolcri (1807). Sepulchres and Other Poems, Trans. J. G. Nichols. Richmond: Oneworld Classic, 2009.

Gaiba, Carla. Il tempo delle passioni. Saggio su 'Le Confessioni d'un Italiano' di Ippolito Nievo. Bologna: Il Mulino, 2001.

O'Gorman, Frank and Lia Guerra (ed.). The Centre and the Margins in $18^{\text {th }}$ Century British and Italian Cultures. Newcastle: Cambridge Scholars Publishing, 2013.

Maffei, Giovanni. Ippolito Nievo e il romanzo di transizione. Napoli: Liguori, 1990.

Manzoni, Alessandro. I promessi sposi (1840); The Betrothed, Trans. by Bruce Penman. London: Penguin, 1972.

Mazzacurati, Giancarlo (ed.). Effetto Sterne. La narrazione umoristica in Italia da Foscolo a Pirandello. Pisa: Nistri-Lischi, 1990.

Mazzacurati, Giancarlo. Il fantasma di Yorick. Laurence Sterne e il romanzo sentimentale, a cura di Matteo Palumbo. Napoli: Liguori, 2006.

Melli, Grazia. ' 'Io non sono divoto”. La fede laica di Carlino Altoviti.' Italianistica 40:2 (2011) $47-55$.

Mengaldo, Pier Vincenzo. Studi su Ippolito Nievo: Lingua e narrazione. Udine: Esedra, 2011.

Missinne, Lut. 'Autobiographical Novel.' In: Martina Wagner-Egelhaaf (ed.), Handbook of Autobiography/Autofiction. Volume I: Theory and Concepts. Berlin/Boston: De Gruyter, 2019, 464-472.

Nievo, Ippolito. Confessioni di un Italiano (1867); Confessions of an Italian, Trans. Federika Randall. London: Penguin, 2014.

Nievo, Ippolito. Novelliere campagnolo, vols. 1 and 2. Bologna: Zanichelli, 2009.

Nievo, Ippolito. In: Marcella Gorra (ed.), Lettere, Tutte le opere, vol. 6. Milano: Mondadori, 1981.

Olivari, Francesco. Ippolito Nievo. Lettere e confessioni. Studio sulla complessità letteraria. Torino: Genesi, 1993.

Olivieri, Ugo Maria. L'idillio interrotto. Forma-romanzo e 'generi intercalari' in Ippolito Nievo. Milano: Franco Angeli, 2002.

Portinari, Folco. Ippolito Nievo. Stile e ideologia. Milano: Silva, 1969.

Romagnoli, Sergio. Di Nievo in Nievo. Roma: Edizioni di storia e letteratura, 2013.

Santiloni, Mariarosa (ed.). Ippolito Nievo: l'avventura del romanzo. Atti della Giornata di Studio all'Università degli Studi di Roma 'Tor Vergata', 11 aprile 2013. Firenze: Franco Cesati, 2013. 
Smith, Sidonie and Julia Watson (ed.). Reading Autobiography. A Guide for Interpreting Life Narratives. Minneapolis: University of Minnesota Press, 2001.

Wagner-Egelhaaf, Martina (ed.). Handbook of Autobiography/Autofiction. 3 Vol. Berlin/Boston: De Gruyter, 2019.

Wolfzettel, Friedrich. 'Die Confessioni d'un Italiano von Ippolito Nievo: Risorgimento und Autobiographie.' Italienisch 33:2 (2011) 14-31.

\section{ABOUT THE AUTHOR}

Chiara Nannicini Streitberger, born in Milan (Italy), is a Professor of Italian Literature at the University St. Louis in Brussels. She taught Comparative and Italian Literature at several universities: Paris III and Paris XII, Caen and Lille (France), Brussels and Namur (Belgium), and was an Invited Professor at the University of Regensburg and at the University of Ghent. Her research deals with Testimony, Autobiography, Literature in different Media, and Relationships between Literature and History. In 2009, La revanche de la discontinuité was published (Brussels: Peter Lang), in 2017 appeared "Ricordate compagni?" (Florence: Cesati). Email: chiara.nannicini@usaintlouis.be.

\section{NOTES}

1 Nievo, Ippolito. Confessioni di un Italiano (1867); Confessions of an Italian, Trans. Federika Randall. London: Penguin, 2014.

2 Nievo, Ippolito. Novelliere campagnolo, vol. 1 and 2. Bologna: Zanichelli, 2009.

3 Nievo, Ippolito. Lettere, Marcella Gorra (ed.). In: Tutte le opere, vol. 6. Milano: Mondadori, 1981.

4 In the words of Folco Portinari. In: Folco Portinari (ed.). Ippolito Nievo. Stile e ideologia. Milano: Silva, 1969 (5).

5 Missinne, Lut. 'Autobiographical Novel.' In: Martina Wagner-Egelhaaf (ed.). Handbook of Autobiography/Autofiction. Volume I: Theory and Concepts. Berlin/Boston: De Gruyter, 2019 (464).

6 See for instance Smith, Sidonie and Julia Watson (ed.). Reading Autobiography. A Guide for Interpreting Life Narratives. Minneapolis: University of Minnesota Press, 2001.

7 Lejeune, Philippe. Le pacte autobiographique. Paris: Le Seuil, 1975.

8 Wagner-Egelhaaf, Martina. 'Autobiography/Autofiction across Disciplines.' In: Martina Wagner-Egelhaaf (ed.). Handbook of Autobiography/Autofiction. Volume I (3) 1-7.

9 Missinne, 'Autobiographical Novel,' 464.

10 Nievo, Confessions of an Italian, 3.

11 Idem, 71.

12 See for example Dionisotti, Carlo. 'Appunti sul Nievo.' In: Appunti sui moderni. Foscolo, Leopardi, Manzoni e gli altri. Bologna: Il Mulino, 1988 (344-345) and, more recently, Wolfzettel, Friedrich. 'Die Confessioni d'un Italiano von Ippolito Nievo: Risorgimento und Autobiographie.' Italienisch 33:2 (2011) 14-31.

13 Among Nievo's sources is Botta's History of Italy from 1789 to 1814. Further information in Dionisotti. 'Appunti sul Nievo.' 1988 (346).

14 Chaarani Lesourd, Elsa. Ippolito Nievo. Uno scrittore politico. Venezia: Marsilio, 2011 (20).

15 Manzoni's masterpiece The Betrothed, seen as a model by the following generation of Italian writers, deals with a more ancient history. Manzoni, Alessandro. The Betrothed (1840). London: Penguin, 1972. 
16 For Scott, see Bigazzi, Roberto. 'Da Waverley a Carlino.' In: Mariarosa Santiloni (ed.), Ippolito Nievo: l'avventura del romanzo. Atti della Giornata di Studio all'Università degli Studi di Roma 'Tor Vergata,' 11 aprile 2013. Firenze: Franco Cesati, 2013 (17-24). For Tolstoy, see Chaarani Lesourd, Ippolito Nievo, 2011, 133.

17 See Romagnoli, Sergio. Di Nievo in Nievo. Roma: Edizioni di storia e letteratura, 2013, 3.

18 Bobbio, Norberto. Old Age and Other Essays. Trans. A. Cameron. Cambridge: Polity Press, 2001.

19 Bobbio, Norberto. 'Reflections of an Octogenarian.' In: Bobbio (ed.), Old Age and Other Essays. 2001, 63. Bobbio adopts a point of view similar to Nievo's, taking a cue from a novel to which he feels very close, as he says, for he was born on the same day as Carlo Altoviti (62).

20 Nievo, Confessions of an Italian, 113.

21 About the close relationship that, in this novel, unites the narrator with his or her target reader, see Gaiba, Carla. Il tempo delle passioni. Saggio su 'Le Confessioni d'un Italiano' di Ippolito Nievo. Bologna: Il Mulino, 2001.

22 Mario Isnenghi must have been the first one to use these terms, for other critics quote them: Maffei, Giovanni. Ippolito Nievo e il romanzo di transizione. Napoli: Liguori, 1990 (125); Mengaldo, Pier Vincenzo. Studi su Ippolito Nievo: Lingua e narrazione. Udine: Esedra, $2011(158,228)$.

23 For instance: 'for as I think about it today,' or 'today.' Nievo, Confessions of an Italian, 2014, 15, 16, 23.

24 See 'I speak, of course, of times past,' idem, 32.

25 Idem, 113, 370.

26 Idem, 27.

27 Idem, 168.

28 See Maffei. Ippolito Nievo e il romanzo di transizione. 1990 (87-120); Falcetto, Bruno. L'esemplarità perfetta. Le 'Confessioni' di Ippolito Nievo. Venezia: Marsilio, 1998 (156-160). Di Benedetto writes: 'nostalgia, emphasis, judgement, irony: these observation manners coexist and are inextricably bound in the Confessions' (my translation). Di Benedetto, Arnaldo. Ippolito Nievo e altro Ottocento. Napoli: Liguori, 1996 (131).

29 Mazzacurati, Giancarlo (ed.). Effetto Sterne. La narrazione umoristica in Italia da Foscolo a Pirandello. Pisa: Nistri-Lischi, 1990; and Mazzacurati, Giancarlo. Il fantasma di Yorick. Laurence Sterne e il romanzo sentimentale. In: M. Palumbo (ed.). Napoli: Liguori, 2006; see also Di Benedetto, Ippolito Nievo e altro Ottocento, 121; O'Gorman, Frank, and Lia Guerra (ed.). The Centre and the Margins in $18^{\text {th }}$ Century British and Italian Cultures. Newcastle: Cambridge Scholars Publishing, 2013.

30 Mazzacurati, Il fantasma di Yorick, 2006, 113. For Sterne's reception in Italy in the 1850s, especially in the literary reviews Il Caffè and L'Arte, see also Olivieri, Ugo Maria. Lidillio interrotto. Forma-romanzo e 'generi intercalari' in Ippolito Nievo. Milano: Franco Angeli, 2002 (165-167).

31 Mazzacurati finds clues that are 'a spy of a sternism no longer and not only linked to Foscolian mediation.' In: Mazzacurati (ed.), Il fantasma di Yorick, 2006, 113 (my translation).

32 See when Mengaldo affirms that 'Sterne's influence upon Nievo has been exaggerated.' In: Mengaldo (ed.), Studi su Ippolito Nievo, 2011, 183. (my translation).

33 Mazzacurati, Giancarlo. 'Segnali e tracce di Sterne nell'opera di Ippolito nievo e il "sentimental humour”.' In: Mazzacurati (ed.), Il fantasma di Yorick, 107-116. He writes: 'He also fell into Sterne's trap, as many others will fall into it after him' (115; my translation).

34 The 'conventional puppet theatre of Fratta's high society,' Falcetto, L'esemplarità perfetta, 1998, 160 (my translation).

35 Nievo, Confessions of an Italian, 2014, 48.

36 Idem, 54. 
37 Maffei, Ippolito Nievo e il romanzo di transizione, 125-126. For further information about Nievo's digressions, see Falcetto, L'esemplarità perfetta, 146.

38 Maffei, Ippolito Nievo e il romanzo di transizione, 124 (my translation).

39 See for example: 'I had better tell you this quickly.' Nievo, Confessions of an Italian, 698, 699.

40 Idem, 710.

41 Idem, 701.

42 Idem, 705.

43 As has already been observed by Di Benedetto, Ippolito Nievo e altro Ottocento, 129.

44 Well described in Chaarani Lesourd, Ippolito Nievo, 2011, 15-16.

45 Bruno Falcetto analyzes the characteristics of the old man's speech, without questioning his attitude in Falcetto, L'esemplarità perfetta, 155-156. See also Olivari, Francesco. Ippolito Nievo. Lettere e confessioni. Studio sulla complessità letteraria. Torino: Genesi, 1993 (76-79).

46 Romagnoli, Di Nievo in Nievo, 9.

47 Ibidem.

48 Nievo, Confessions of an Italian, 14, 15, 441.

49 Idem, 440.

50 Idem, 5 .

51 Idem, 859.

52 Melli, Grazia. '“Io non sono divoto.” La fede laica di Carlino Altoviti.' Italianistica 40:2 (2011) 47-55.

53 Nievo, Confessions of an Italian, 71.

54 On the last pages of the novel. Idem, 859.

55 Ibidem.

56 Idem, 113.

57 Bergson, Henri. Time and Free Will. An Essay on the Immediate Data of Consciousness. Toronto: Great Library Collection, 2015 (106).

58 Foscolo, Ugo. I Sepolcri (1807). Sepulchres and other poems. Trans. J. G. Nichols. Richmond: Oneworld Classic, 2009 (49-65).

59 Nievo, Confessions of an Italian, 307.

60 Idem, 306.

61 Idem, 322.

62 Idem, 465.

63 Idem, 466.

64 Idem, 466-467. 